\title{
Slamming the Door on Trade Policy Discretion? The WTO Appellate Body's Ruling on Market Distortions and Production Costs in EU-Biodiesel (Argentina)
}

Jennifer A. Hillman

Georgetown University Law Center, jah95@georgetown.edu

Meredith A. Crowley

Faculty of Economics, University of Cambridge, meredith.crowley@econ.cam.ac.uk

This paper can be downloaded free of charge from:

https://scholarship.law.georgetown.edu/facpub/2063

https://ssrn.com/abstract=3155320

Jennifer A. Hillman \& Meredith A. Crowley, Slamming the Door on Trade Policy Discretion? The WTO Appellate Body's Ruling on Market Distortions and Production Costs in EU-Biodiesel (Argentina), 17 World Trade Rev. 195-213 (2018). 

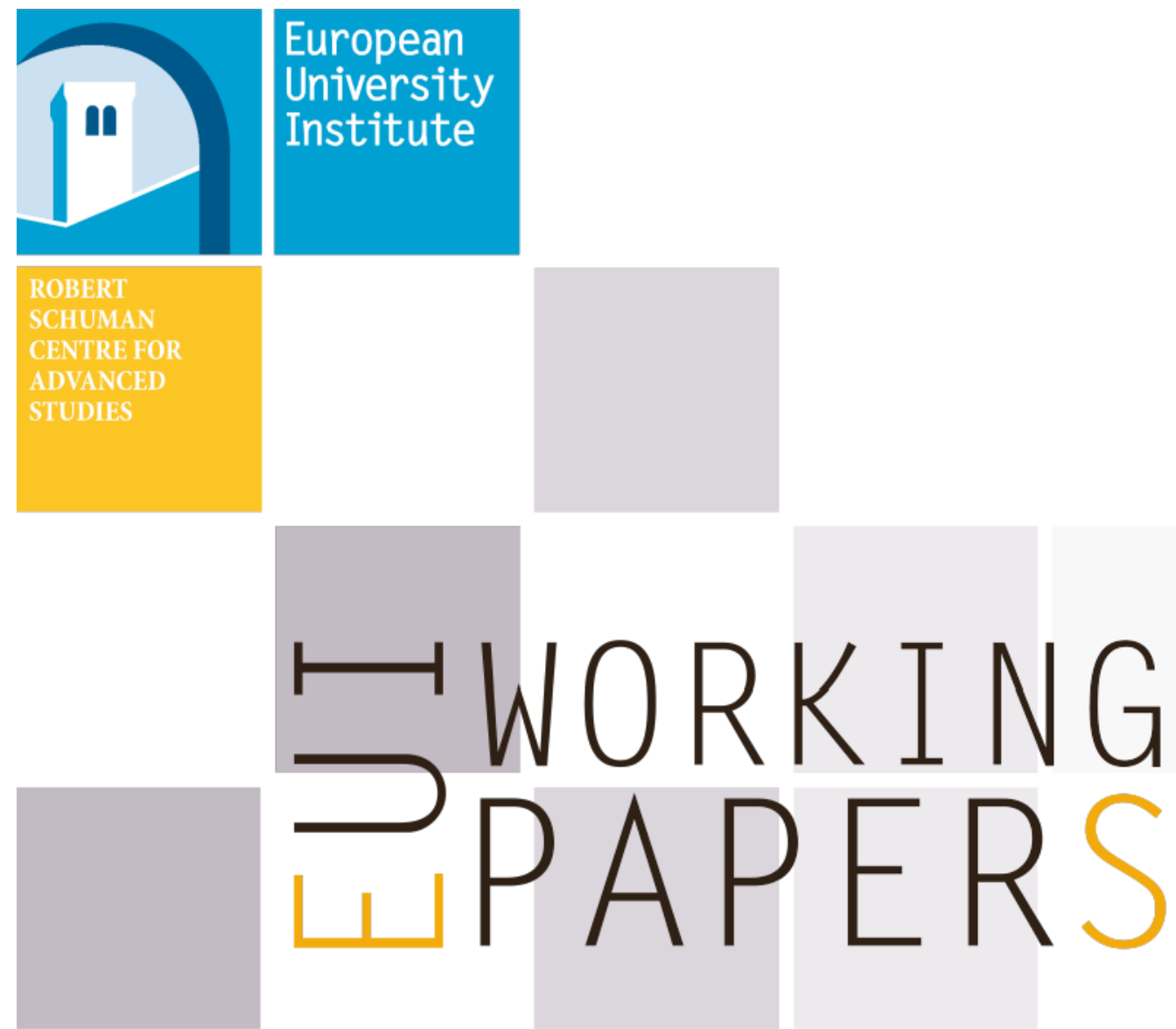

\section{RSCAS 2017/61}

Robert Schuman Centre for Advanced Studies Global Governance Programme-286

Slamming the door on trade policy discretion? The WTO Appellate Body's ruling on market distortions and production costs in EU-Biodiesel (Argentina)

Meredith A. Crowley and Jennifer A. Hillman 
European University Institute

Robert Schuman Centre for Advanced Studies

Global Governance Programme

Slamming the door on trade policy discretion?

The WTO Appellate Body's ruling on market distortions and production costs in $E U$-Biodiesel (Argentina)

Meredith A. Crowley and Jennifer A. Hillman

EUI Working Paper RSCAS 2017/61 
This text may be downloaded only for personal research purposes. Additional reproduction for other purposes, whether in hard copies or electronically, requires the consent of the author(s), editor(s). If cited or quoted, reference should be made to the full name of the author(s), editor(s), the title, the working paper, or other series, the year and the publisher.

ISSN 1028-3625

(C) Meredith A. Crowley and Jennifer A. Hillman, 2017

Printed in Italy, December 2017

European University Institute

Badia Fiesolana

I - 50014 San Domenico di Fiesole (FI)

Italy

www.eui.eu/RSCAS/Publications/

www.eui.eu

cadmus.eui.eu 


\section{Robert Schuman Centre for Advanced Studies}

The Robert Schuman Centre for Advanced Studies (RSCAS), created in 1992 and directed by Professor Brigid Laffan, aims to develop inter-disciplinary and comparative research and to promote work on the major issues facing the process of integration and European society.

The Centre is home to a large post-doctoral programme and hosts major research programmes and projects, and a range of working groups and ad hoc initiatives. The research agenda is organised around a set of core themes and is continuously evolving, reflecting the changing agenda of European integration and the expanding membership of the European Union.

Details of the research of the Centre can be found on:

http://www.eui.eu/RSCAS/Research/

Research publications take the form of Working Papers, Policy Papers, Policy Briefs, Distinguished Lectures, Research Project Reports and Books.

Most of these are also available on the RSCAS website:

http://www.eui.eu/RSCAS/Publications/

The EUI and the RSCAS are not responsible for the opinion expressed by the author(s).

\section{The Global Governance Programme at the EUI}

The Global Governance Programme is one of the flagship programmes of the Robert Schuman Centre for Advanced Studies at the European University Institute (EUI). It aims to: build a community of outstanding professors and scholars, produce high quality research and, engage with the world of practice through policy dialogue. At the Global Governance Programme, established and early career scholars research, write on and discuss, within and beyond academia, issues of global governance, focussing on four broad and interdisciplinary areas: European, Transnational and Global Governance; Global Economics; Europe in the World; and Cultural Pluralism.

The Programme also aims to contribute to the fostering of present and future generations of policy and decision makers through its unique executive training programme, the Academy of Global Governance, where theory and "real world" experience meet. At the Academy, executives, policy makers, diplomats, officials, private sector professionals and academics, have the opportunity to meet, share views and debate with leading academics, top-level officials, heads of international organisations and senior executives, on topical issues relating to governance.

For more information: http://globalgovernanceprogramme.eui.eu 



\begin{abstract}
This paper presents a legal-economic analysis of the Appellate Body's decision that the WTO's AntiDumping Agreement (ADA) precludes countries from taking into account government-created price distortions of major inputs when calculating anti-dumping duties, made in EU-Biodiesel (Argentina). In this case, the EU made adjustments to the price of biodiesel's principal input - soybeans - in determining the cost of production of biodiesel in Argentina. The adjustment was made based on the uncontested finding that the price of soybeans in Argentina was distorted by the existence of an export tax scheme that resulted in artificially low soybean prices. The Appellate Body found that the EU was not permitted to take tax policy-induced price distortions into account in calculating dumping margins. We analyze the economic rationale for Argentina's export tax system, distortions in biodiesel markets in Argentina and the EU, and the remaining trade policy options for addressing distorted international prices. We also assess whether existing subsidies disciplines would be more effective in addressing this problem and conclude that they would not.
\end{abstract}

\title{
Keywords
}

WTO, anti-dumping, export tax, cost adjustment, government distortion, subsidy

JEL Classification: F13, F53. 



\section{Introduction}

The dispute between the EU and Argentina over the application of European antidumping duties on biodiesel imported from Argentina raises big questions about the functioning of the WTO Agreements when confronted with problems that are not explicitly addressed in the treaty text or that may fall in the cracks between the WTO's Agreement on Anti-dumping (ADA) and its Agreement on Subsidies and Countervailing Measures (SCM). In this case, an economic policy by one country (Argentina) had a trade-distorting effect that was similar to a production subsidy, but it was not clear what legal provisions of the WTO were most appropriate for addressing and offsetting the underlying price distortion. Anti-competitive practices by private firms that lead to distorted international prices are typically addressed by the imposition of anti-dumping duties, consistent with the ADA. In contrast, government intervention that confers financial benefits on exporting firms and distorts international prices is typically addressed through the application of countervailing duties under the SCM Agreement. A narrow legal interpretation of either the ADA or the SCM could leave an importing country with no options to address low-priced imports that harm domestic producers when those low prices are caused by distortions in markets for inputs.

The meta-problem highlighted by this case is the interaction of market economies with non-market economies. A distortion affecting prices in one sector of the economy that is caused by a government policy can pass-through into the prices of internationally traded goods. Thus, a case could be made for some kind of trade remedy in the importing country. However, the letter of the WTO law is not wellsuited to analyzing distortions that are one or two degrees removed from the internationally traded good. Assessing the impact of a market intervention that is one or two degrees away from the internationally trade good requires the use of econometrics. Methodologies for assessing dumping margins have been the focal point of a number of trade remedy disputes. ${ }^{1}$ The WTO agreement will continue to face challenges arising from not only the "Non-Market Economy" status of some WTO members, but also with issues that could arise for vertically integrated global firms and for firms in vertically-structured industries.

Interestingly, the addendum to the AB Report summarizing the third party submissions in this case demonstrates that support for Argentina compared to the EU appears to follow a strict party line in which the more market-based economies with lower levels of government intervention supported the EU's position (e.g. the US) whereas the economies characterized by extensive government involvement in markets favored Argentina's arguments (e.g. Saudi Arabia and China).

Our analysis focuses on what we see as the most important aspect of the dispute and the AB's ruling - the use of alternative data to construct production costs for an exporter. ${ }^{2}$

This dispute follows a long line of WTO challenges to anti-dumping measures where the heart of the challenge relates to adjustments to prices made by the investigating authorities (here, the European Commission) to data presented to it by exporting producers. ${ }^{3}$ In this case, the EU imposed antidumping duties on imports of biodiesel fuel exported from Argentina, where soybeans were the

1 See Horn and Mavroidis (2006), Bown and Sykes (2008), Prusa and Vermulst (2009) and Crowley and Howse (2010) for a discussion of challenges to dumping methodologies in previous WTO disputes.

2 While the AB report included findings with respect to the WTO constituency of certain provisions of the EU's Basic Antidumping regulation, the amount of dumping duties imposed and the EU's reliance on certain capacity data as part of its injury findings, with the exception of Table 1, we leave those issues aside.

3 Other legal-economic assessment of related disputes in this series include BOWN, C., \& SYKES, A. (2008). The Zeroing Issue: A critical analysis of Softwood V. World Trade Review, 7(1), 121-142. doi:10.1017/S1474745607003564; Horn, H., \& Mavroidis, P. (2006). European Community - Antidumping Duties on Malleable Cast Iron Tube or Pipe Fittings from Brazil (WT/DS219/AB/R: DSR 2003:VI, 2613). World Trade Review, 5(S1), 87-129. doi:10.1017/S1474745606001418. 
primary input material used by Argentine biodiesel producers. In constructing a home (i.e. Argentine) market price for Argentine biodiesel, the Commission chose to adjust the price of soybeans in order to compensate for the distortion in soybean prices caused by an export tax scheme imposed on soybeans, soybean oil and biodiesel by the Argentine government. There was no dispute that Argentina used this tax to discourage exports of soybeans and to keep the price of soybeans low; the data on record shows Argentine soybean prices were about 35 percent below international soybean prices. ${ }^{4}$ A lower price for soybeans implies a lower margin of dumping than would have been the case if Argentine producers had paid the international or a non-distorted price for soybeans.

This case thus raises the question of whether the WTO's Anti-Dumping Agreement (ADA) permits countries to take government-created distortions to the price of major inputs into account when calculating the home-market price of allegedly dumped goods. The answer from the Appellate Body is no and that answer likely has significant implications not only for this case but for all cases in which investigating authorities are faced with distorted home market prices, particularly in non-market economies such as China and Vietnam.

In this article, we begin with an analysis of the legal and economic merits of the case presented to the $\mathrm{AB}$ for resolution. We then proceed to a counterfactual discussion of whether the economic situation involving Argentine biodiesel should have proceeded in the EU as an anti-subsidy case. Interestingly, an anti-subsidy case was filed almost simultaneously with the antidumping case. However, the anti-subsidy case was withdrawn by the European domestic producers and terminated by the Commission shortly after the Commission issued its final determination to impose antidumping duties. In discussing the subsidy issues at play in this case, we point out an important gap in the current WTO rules governing the interaction of market and non-market economies.

\section{Background of the EU Antidumping Measure on Biodiesel}

In August 2012, the European Biodiesel Board (EBB), representing biodiesel producers in Europe, filed a complaint contending that imports of biodiesel from Argentina and Indonesia were being sold in Europe for less than they sold for at home and that these low-priced imports were injuring European biodiesel producers. In most dumping cases, the amount of dumping is determined by comparing the price at which the good is sold in its home market (Normal Value) with the price at which it is sold in the importing country. ${ }^{5}$ However, the ADA permits Investigating Authorities (IAs) to depart from using home market sales prices: 1) when there are no home market sales of the product "in the ordinary course of trade," or 2) when a particular market situation or a low volume of sales does not permit a proper comparison. (ADA Art. 2.2) Here, the EBB contended (and the Commission found) that the Argentine involvement in regulating all aspects of biodiesel production was so extensive that domestic prices for sales of biodiesel could not be used to determine the Normal Value (i.e., they were no sales "in the ordinary course of trade"). ${ }^{6}$ Because all dumping determinations involve a comparison

4 The Argentines challenged European assumptions about what the international, world-market price would have been in the absence of the Argentine export tax system. We take this up in Sections III and VI below.

Dumping is considered to have occurred whenever thde Export Price is below the Normal Value (or home-market price) of a good. For example, if biodiesel sold for \$10 per gallon in Argentina but sold for \$7 per gallon in Europe, dumping in the amount of $\$ 3$ per gallon would be found. Anti-dumping duties equal to the amount of dumping can be imposed if an Investigating Authority also determines that the dumped imports caused material injury to the domestic producers of the good. A low (potentially dumped) price confers an economic benefit to consumers in Europe, but harms EU biodiesel producers forced to compete with a significant volume of low-priced imports. The Commission's (and the WTO ADA's) viewpoint that low prices are a problem assumes that EU producers' well-being is more important than that of EU consumers. This is a normative question that we set aside for the moment.

6 The EU asserted and no party contested that sales in Argentina were not "in the ordinary course of trade." As such, neither the Panel nor the Appellate Body attempted to further define "ordinary course of trade," nor were the other bases 
between Normal Value and the Export Price of a good, the Commission was forced to look to alternatives to the sales prices in Argentina to determine a Normal Value. The ADA provides for two basic alternatives to the use of home market sales prices: 1) prices for sales in a third country market or 2) the cost of production (COP) plus selling, general and administrative expenses plus a reasonable profit. The Commission opted to use the COP alternative to construct a Normal Value.

To conduct its COP analysis, the Commission was required to determine the price of the key inputs used in Argentina to make biodiesel. Chief among these was soybeans and soybean oil. In the preliminary phase of its investigation, the Commission stated that it did not have sufficient information to address the EBB's contention that the price of soybeans and soybean oil was itself too distorted to be used in determining the cost of production for biodiesel but that it would take up the issue in the final, definitive stage of the investigation. Therefore, for its provisional decision, the Commission used the cost of soybeans and soybean oil as reflected in the books and records of the selected Argentine producers (i.e., the distorted input price) and on that basis, found that biodiesel from Argentina had been dumped in Europe at margins of dumping ranging from $6.8 \%$ to $10.6 \%$.

In the final phase of its investigation, the Commission examined the domestic prices of soybeans and soybean oil and found: 1) that Argentina's export tax system resulted in prices for soybeans that were considerably below the international price, and 2) that the reference price used by the Argentine government to calculate the export tax on soybeans reflected the international price of soybeans. As a result, the Commission decided to use the Argentine reference price (minus certain transport "fobbing" costs) in lieu of the actual prices paid by Argentine producers when determining the cost of the raw materials used to produce biodiesel. The Commission reasoned that this reference price is what "would have been the price paid ... in the absence of the export tax system." As a result of using these reference prices, the Commission found much higher margins of dumping than in the preliminary phase, with dumping margins ranging from $41.9 \%$ to $49.2 \%{ }^{8}$

How and why were the home market prices of Argentine biodiesel distorted? The basic economics suggest that the price of Argentine biodiesel was low relative to what it would have been in the absence of the export taxes on soybeans and soybean products. Biodiesel's primary input is soybeans (75-80\% of costs) which were very cheap in Argentina because the Argentine government applied a high export tax on raw soybeans and a lower export tax on biodiesel, a higher-value added commodity. This Argentine policy presumably was designed to have two effects; first, by placing a higher tax on the raw commodity than on a more processed good, the Argentine government was attempting to raise the value-added component of Argentina's exports and aid the economy in moving up the value chain in its exports; second, by putting downward pressure on the domestic price of the primary input into biodiesel, raw soybeans, the government policy was a directed financial transfer to biodiesel producers at the expense of soybean farmers. In other words, the government offered biodiesel producers a de facto production subsidy (a financial benefit that was specific to the industry), but the cost of this subsidy program was borne by sellers of soybeans who received low, tax-distorted prices. By structuring the intervention as an export tax on an input rather than a direct production subsidy (a subsidy to purchasing the input), the cost of the program appeared on the government balance sheet as tax revenue (rather than an expenditure), yet still conferred benefits that were clearly specific to a single industry - biodiesel production. ${ }^{9}$

(Contd.)

for departing from the use of Normal Value ("particular market situation" or "low volume of sales") addressed in this dispute.

7 AB Report, para. 5.8, referring to Panel Report, para. 7.257 and Definitive Disclosure (Panel Exhibit ARG-35) para. 32.

8 Because the EU applies a lesser duty rule and the Commission found that the injury margins were at rates ranging from $22 \%$ to $25.7 \%$, those lesser rates were the rates definitively applied by the EU rather than the $41.9 \%$ to $49.2 \%$ dumping margins.

9 The question of who bore the burden of (i.e. paid) the export tax on soybeans depends on the conditions of competition in the international market for soybeans, that is, the elasticities of export supply and import demand. We take this up further in section VI. 


\section{Does the Anti-Dumping Agreement Permit the Use of Alternatives to Actual Costs?}

The heart of the dispute between the EU and Argentina rests on the disparate views of what data investigating authorities (IAs) conducting anti-dumping investigations are required to use when determining the Normal Value of allegedly dumped goods. Argentina's basic contention is that ADA requires IAs to use the actual prices paid for goods in the country of origin, no matter how distorted or far from "reality" such prices might be. If the prices are reflected in actual books and records of companies as what they actually paid for inputs, then the IA must rely on them. The EU, on the other hand, claims that there is an overarching standard of reasonableness that permits IAs to look elsewhere when the actual prices are not reasonable and that IAs are not required to blindly follow actual prices paid if those prices bear no rational relationship to a "real" price due to government interventions that distort the actual prices. ${ }^{10}$

As such, the dispute centers on the interpretation of two provisions found in ADA Article 2:

1) Article 2.2, which permits IAs to abandon home market sales prices when, among others, there are no sales of the like product in the ordinary course of trade and to look to alternatives for determining Normal Value, including the "cost of production in the country of origin plus a reasonable amount for administrative, selling and general costs and for profits," which are often lumped together as simply the Cost of Production (COP). There was no dispute in this case over the EU decision not to use home market sales prices or to the decision to opt for a COP analysis. Rather the dispute centered on the COP assumptions and methodology used by the EU.

The Argentines never contested that their tax policy reduced the domestic price of soybeans. In fact, their position during the EU's original investigation was two-fold: first, the export tax system was permitted under WTO rules and, second, the resulting low input prices were most appropriately seen as "the natural competitive advantage of the Argentine producers." In their view, the tax system conferred on Argentine producers a fair competitive advantage that created real welfare gains for the Argentine firms' European customers. Throughout the EU's original antidumping investigation and the WTO dispute, Argentina argued that the Commission was incorrectly interpreting the ADA and was wrong to use international soybean prices in constructing the cost of domestic biodiesel producers.

The legal issue under Article 2.2 was whether the EU, in using a reference price established by the Argentine government based on international prices, had correctly found the COP in Argentina, the country of origin. The EU contended that the soybean prices it used reflected the soybean costs that the producers of biodiesel would pay in Argentina absent the distortion caused by the Argentine export tax system. As such, the EU argued that these prices were costs "in the country of origin" within the meaning of ADA Article 2.2.

Argentina, on the other hand, submitted that the phrase in Article 2.2 "cost of production in the country of origin" refers only to expenses incurred in the production of the product at issue in the country of origin, which can only be determined by using information and evidence from the country of origin - and not through the use of international prices or outside benchmarks.

In its analysis, the Appellate Body first rejected the basic notion that outside information or evidence can never be used to determine COP inside the country of origin. It then established the following test: "when relying on any out-of-country information to determine the cost of production in

10 The EU concluded that "the domestic prices of the main raw material used by biodiesel producers in Argentina were ... lower than the international prices due to the distortion created by the Argentine export tax system and, consequently, the costs of the main raw material were not reasonably reflected in the records kept by the Argentinean producers." Panel Report, para. 7.181.

11

Council Implementing Regulation (EU) No 1194/2013 in Official Journal of the European Union L 315/6(41) of 26 November 2013. 
the country of origin under Article 2.2, an investigating authority has to ensure that such information is used to arrive at the 'cost of production in the country of origin', and this may require the investigating authority to adapt that information." (para. 6.82, emphasis added). As such, the Appellate Body is stating that the only permitted analysis is one that ends with the cost of production in the country of origin. As such, it appears that the right to use outside information may have been given with one hand, while, as a practical matter, been taken away with the other, as it is likely to be extremely difficult, if not impossible, for an IA to meet the Appellate Body's test. Any IA wishing to rely on outside information bears the burden of showing that any outside information used nonetheless results in a determination of prices inside the country of origin. How is an IA supposed to make such a showing? It is precisely because prices inside a country are unavailable or not usable or distorted that the IA would have turned to outside benchmarks in the first place. Moreover, it is not clear what the Appellate Body means by "arrives at." If it means that the outside information must produce a cost that is equal to the inside country price, then there would be no reason to resort to outside information or prices if the result must be the same. If the prices or costs inside the country of origin are distorted, it is not clear why the IA should be required to "arrive at" that same distorted price.

Indeed, the Appellate Body's reasoning with respect to Article 2.2 appears to be the ultimate Catch-22. The Appellate Body notes that the EU opted to use a surrogate price for soybeans precisely because the surrogate price did not represent the cost for soybeans in Argentina (which the EU had found to be distorted due to the export tax scheme) but then found that the EU violated Article 2.2 because the surrogate used did not represent the cost of soybeans in Argentina. It is hard to imagine how any IA would ever be able to prove that the domestic prices cannot be used due to distortions or unavailability and at the same time find a surrogate price that it can prove represents those same domestic prices (presumably as they would have been absent distortions).

Two distinct and important issues were confounded by the AB's Catch-22 ruling. First, what is dumping? In other words, are exporters dumping if they set prices to maximize profits given a locally available input price? Or, if an input price is favorably distorted by a government policy, does this automatically imply dumping by a profit-maximizing firm? Second, what guidance does the treaty provide on how an Investigating Authority determines the cost of production of an exported good? Does it provide any guidance on how to determine the "true" price of an input in the presence of a distortive tax or subsidy? In other words, is this entire line of analysis conducted by the EU permitted under Article 2.2?

The answer to the first question requires an almost philosophical response; most economists object to the legal definition of dumping provided by Article 2.2 and instead interpret "dumping" to refer to an anticompetitive behavior by a firm that is intended to eliminate competitors or increase a firm's market power so that the firm can raise prices in the future. Economists condemn anti-competitive practices but generally approve of pricing strategies, such as temporarily pricing below cost, that are prohibited by Article 2.2. Viewed in this light, the prices of Argentine biodiesel producers were the outcome of normal profit-maximizing behavior and did not constitute dumping in the anticompetitive behavior sense. However, if an economic analysis were premised on the Article 2.2 definition of dumping as pricing below cost, the question of how to construct cost appropriately becomes relevant. The Argentine view was that the price of soybeans in Argentina, inclusive of the effect of any taxes, was the relevant price for determining costs. From an accounting perspective, the prevailing price of the input inclusive of taxes and subsidies would be the correct price for determining the firm's profits. Logically, that same input price should be used for other analyses.

However, the problem that arises with using the prevailing price of the primary input in the country of origin to construct costs is that it ignores the trade-distorting impact of the actions of the Argentine government. This leads to the second question, how should an Investigating Authority determine the price of an input for constructing costs and estimating dumping margins? The convoluted language of the $\mathrm{AB}$ seems to rule out using information other than local information precisely when local market information is unavailable. Into this information vacuum, the remaining option the AB inadvertently 
left on the table is an econometric approach to estimating the input price in the country of origin. An econometric approach would use Argentine data to estimate the export supply elasticity facing Argentina together with information on the local tax program to estimate the local input price in the absence of the tax program. Interestingly, the procedure the Commission followed, which ignored econometrics and used the international market price as the reference price for soybeans, would have arrived at the same conclusion as an econometric analysis if the global export supply of soybeans were perfectly elastic. If Argentina faced an almost perfectly elastic export supply curve, the domestic price of soybeans in the absence of Argentina's export tax policy would have been equal to the international price. ${ }^{12}$

2) Article 2.2.1.1, which explains how the COP is to be determined, specifically states that "cost shall normally be calculated on the basis of records kept by the exporter or producer . . . provided that such records are in accordance with the generally accepted accounting principles of the exporting country and reasonably reflect the costs associated with the production and sale of the product under consideration." (ADA Art. 2.2.1.1).

The dispute here centered on the second condition for using the books and records of the exporter or producer - that they reasonably reflect the costs associated with the production and sale of the product under consideration. The EU contended that this phrase permits an IA to examine the "reasonableness" of the costs themselves, noting that the costs referred to in Art. 2.2.1.1 "must themselves be 'reasonable' if the records are to reasonably reflect them." (para. 6.35). Argentina, for its part, contended that the IA is only permitted to examine the reliability and accuracy of the costs reported in the records to ensure that they reflect the actual costs paid by the producer or exporter. For Argentina, Article 2.2.1.1 does not allow an IA to assess whether the recorded costs meet some general standard of "reasonableness" through a comparison with hypothetical costs that might prevail in a hypothetical market, free from government regulation or distortion.

The Appellate Body largely agreed with the panel and with Argentina, finding that the phrase "reasonably reflect the costs" means "whether the records kept by the exporter or producer suitably and sufficiently correspond to or reproduce those costs incurred by the investigated exporter or producer that have a genuine relationship with the production and sale of the specific product under consideration." (para.6.26) For the panel and the Appellate Body, the "reasonably reflect" phrase was intended to ensure that the costs were the "actual" cost incurred for the production of the precise product at issue. So long as the books and records reflect the amount actually paid -no matter how ridiculous that amount might be - that amount must be used. In reaching this conclusion, the Appellate Body expressly rejected the EU's attempt to read into the phrase "reasonably reflect the costs" the notion of costs pertaining to the production and sale of biodiesel in "normal circumstances" yet accepted reading in the notion of "actual" costs so long as they were reflected in books and records, even though the word "actual" does not appear in Article 2.2.1.1.

There was no dispute that the prices for soybeans in Argentina were distorted, nor any dispute that the prices did not reflect the world-wide price for a commodity such as soybeans, yet no room found in the ADA not to use them anyway. The Appellate Body interpreted the phrase "reasonably reflect the costs" narrowly, focusing largely on whether the costs in a given producer's books and records accurately reflect the cost of producing the particular like product at issue, since many producers may

12 The Argentines presented an argument against this claim; "CARBIO complained that the Commission did not take into account the fact that in the absence of the DET [export tax] in Argentina, the CBOT [international] prices of soya beans would have been much lower." See Council Implementing Regulation (EU) No 1194/2013 in Official Journal of the European Union L 315/6(41) of 26 November 2013. There is likely some truth to this claim. Argentina's share of the global market for soybeans, soybean meal and soybean oil is substantial and growing. In 2001, Argentina's share of the world market for soybeans and soybean meal was 24\% (See Schnepf, Dohlman, and Bolling; 2001, p. 2). By 2016, the US Department of Agriculture was forecasting that Argentina would capture half of the world market for soybean meal and oil by 2026 (See Lee, Tran, Jansen and Ash; 2016). Together, these facts suggest that Argentina, as a major supplier, was able to exert some market power over international prices through its export tax policy. 
be producing a variety of products in the same facility. As such, for the Appellate Body, the phrase "reasonably reflect the costs" was about whether a proper allocation of costs had been made; the phrase was not read to encompass a broader notion that books and records can accurately record cost figures that are nonetheless "unreasonable" because they are distorted.

\section{Has the Appellate Body Left Any Room to Address Distorted Prices in Anti- Dumping Cases?}

As a result of the Appellate Body's dual findings that use of the alternative COP methodology under Article 2.2 for determining Normal Value must: 1) limit the use of outside benchmarks to those which "arrive at" the costs inside the country of origin and 2) use the actual costs in the books and records of the exporting producer so long as they reflect proper cost allocations, no matter how disconnected they may be from international or "real" market prices, the Appellate Body appears to have left little room in the ADA to address distorted prices or costs in non-market or other economies in which government policies have affected the prices of input material used to produce internationally-traded goods.

This approach to a strict reading of cost comparisons in the ADA stands in fairly stark contrast to the interpretations made with respect to subsidies under the Agreement on Subsidies and Countervailing Measures (SCM). There, for example, a subsidy is deemed to exist if the government purchases goods from a domestic producer at a value that is even slightly above the market price for that good or provides goods or services to company for a price below market value. And outside benchmarks are often used to determine the market prices for goods or services.

Indeed, the jurisprudence on subsidies leaves little doubt that the existence of a financial contribution and a benefit -and hence a subsidy - must be done based on a comparison between a market price and the amount of the government contribution. The Panel in Canada - Aircraft found that "the only logical basis" for determining whether the financial contribution places the recipient in a more advantageous position than it otherwise would have been "is the market."(para 9.112) According to the Panel: "[A] financial contribution will only confer a 'benefit', i.e., an advantage, if it is provided on terms that are more advantageous than those that would have been available to the recipient on the market."(para 9.112) Hence in the subsidies context, the existence of a market price and the determination of that price is a central question for which evidence must be provided. It is not simply assumed based on the books and records of any particular company involved.

With respect to the use of outside benchmarks, the contrast between the Appellate Body's rejection of the Argentine references prices for soybeans used to make biodiesel in the anti-dumping context from the Appellate Body's endorsement in United States - Definitive Anti-dumping and Countervailing Duties on Certain Products from China (US-Anti-Dumping and Countervailing Duties) of outside benchmarks for the price of hot-rolled steel is remarkable. In US-Anti-Dumping and Countervailing Duties, for hot-rolled steel, the Appellate Body stated: "we are of the view that an investigating authority may reject in-country private prices if it reaches the conclusion that these are too distorted due to the predominant participation of the government as a supplier in the market ... It is, therefore, price distortion that would allow an investigating authority to reject in-country private prices, not the fact that the government is the predominant supplier per se. (para. 446). Yet in the context of calculating the COP for biodiesel, the Appellate Body accepted the EU's analysis that the private prices were distorted due to government intervention through the export tax scheme, but nonetheless severely restricted the EU's ability to bring in outside benchmarks to correct for such distortions.

While the Appellate Body's narrow interpretation of the key phrases in Articles 2.2 and 2.2.1.1 of the ADA appears to have shut the door on taking market distortions into account when determining costs of production, there may be a few windows left open. First, by its terms, the AB report is limited to an analysis of the second condition for using records of the exporter (that records "reasonably 
reflect the costs associated with the production and sale of the product under consideration") (fn. 120). Therefore, the $\mathrm{AB}$ leaves open an interpretation of both the first condition for the use of exporter records (i.e., that the records are "in accordance with the generally accepting accounting principles of the country"), and more importantly, the opening phrase in Art 2.2.1.1, that costs shall normally be calculated on the basis of the records ..." As such, the AB has not ruled on whether distortions, particularly in non-market economy countries where separating distorted from non-distorted prices may be especially difficult, can rise to the level of creating an abnormal situation such that deviation from the norm of relying on exporter records is entirely justified.

In addition, the EU's deviation from use of Argentine sales prices was based entirely on its unchallenged determination that there were no sales in the ordinary course of trade. As such, this case does not address what may be the more difficult question of what is meant by "the particular market situation" that would also justify using COP or third country prices in lieu of home market sales prices.

Finally, because Argentina did not challenge the EU determination of a lack of sales in the ordinary course of trade, the $\mathrm{AB}$ left open the question of the relationship between that lack of ordinary course sales and distortions in the market. It is possible that in another case, substantial evidence could be developed about why there were no sales that were considered to be in "the ordinary course," just what that "ordinary course" might be in a given market, and what distortions can be seen to arise from a lack of sales in that "ordinary course" that would support the use of adjustments to costs under the $\mathrm{COP}$ or would mean that exporter records reflect an abnormal situation justifying a departure from the normal reliance on exporters records.

Why such a strict reading of the ADA with respect to the COP methodology? In essence, the AB's decision might be interpreted as strong guidance to re-direct the focus of antidumping policy back to its original purpose - addressing anticompetitive practices by firms - and away from its growing use as a catch-all to offset or correct every type of price distortion that can arise in a non-market or a distorted economy. The deeper puzzle in this case is why the EBB and Commission pursued biodiesel from Argentina as a dumping case rather than an anti-subsidy case when the evidence suggests that the agent ultimately responsible for the low price of exported biodiesel was the Argentine government. Perhaps in restricting discretion in $\mathrm{COP}$ methodologies for dumping cases, the $\mathrm{AB}$ was trying to force countries to use anti-subsidy measures when price distortions arise from government action. Alternatively, because an econometric analysis would allow an Investigating Authority to construct a local input price using local information (rather than information from international or third markets), the $\mathrm{AB}$ might be encouraging the use of more sophisticated econometric methodologies in trade remedy investigations

\section{Alternative approaches to addressing distortions of international prices}

As mentioned previously, the big puzzle in this case is why the EBB and Commission pursued an antidumping case rather than an anti-subsidy case. An anti-subsidy case was initiated by the Commission in November 2012, approximately six weeks after the anti-dumping case was initiated. However, while the dumping case quickly resulted in preliminary results, the anti-subsidy case appears to have stagnated before it was ultimately terminated in November 2013, one month after the Commission's definitive dumping determination.

\section{A. Legal Challenges Faced in Using Subsidies Disciplines}

From a legal standpoint, any effort to turn to subsidies disciplines rather than antidumping immediately runs into the narrowing windows through which subsidy cases must fit in light of recent Appellate Body decisions making subsidies disciplines harder to use. A successful subsidies case involves showing the existence of: 1) a financial contribution, 2) by a government (or public body), 3) 
which confers a benefit and 4) is specific. (SCM Article 1). Argentina's export tax, despite the significant price distortions it created, does not fit neatly into those four requirements, particularly given that the export tax on soybeans resulted in only an indirect effect on biodiesel producers. First, it is hard to characterize the export tax as a financial contribution, as it involves a government collection of revenue from exporters of soybeans, soybean oil and biodiesel, not the provision of government monies to any of those producers. Nor does the export tax result in the provision of a tax exemption that might constitute "foregone revenue" and hence a financial contribution.

Second, to the extent that the export tax could be seen as a financial contribution that confers a benefit, it does so by creating market pressures for low prices for soybeans, not a direct provision of government support to biodiesel producers. While subsidies can be found where the government has provided goods (here, soybeans) for less than adequate remuneration, the Argentine government never owned the soybeans and never directly set the prices at which the soybeans would be sold to biodiesel producers, making it hard to show that the government itself provided below-cost soybeans to the biodiesel producers.

Similarly, a subsidy can be found if, rather than providing the financial contribution and conferring the benefit itself, the government "directs and entrusts" a private body to provide the subsidy in its stead. Here too such a showing would be difficult, as it is not clear that the soybean farmers are standing in the shoes of the government, nor that they have been directed to sell soybeans to biodiesel producers at low prices. Demonstrating such "entrustment and direction" may have been the EU's best option, but obtaining evidence that the Argentine government was acting to ensure that the soybean farmers had no option but to sell low-priced soybeans specifically to biodiesel producers and that such sales were being made by farmers in lieu of a normal government practice of selling soybeans would have been a tall order. ${ }^{13}$

\section{B. Economic Analysis of the Export Tax as a Subsidy}

An economic analysis of this case should begin with a review of the international markets for biodiesel and biodiesel inputs (soybeans and soybean oil) as well as a review of the structure of the markets for both products in Europe, Argentina and other relevant locations. Two important observations are a starting point: firstly, biodiesel consumption is heavily influenced by a myriad of government environmental regulations. It is more expensive than petroleum biodiesel, but many countries require that diesel sold to consumers have a minimum share of renewable biodiesel. This leads to different demand in different regions as well as for different varieties of biodiesel. Second, the primary input into many varieties of biodiesel is soybeans, a commodity that is traded on spot and futures markets. Thus, the global market for soybeans fits the classic definition of a competitive market.

\section{Biodiesel markets and government environmental regulation}

The market for biodiesel is driven by government environmental regulation around the world. In Argentina, the Commission found that the home market price of biodiesel could not be used as a Normal Value because (a) all diesel sold to consumers was regulated to have a biodiesel share of at least 7\% and (b) the price of this mandated biodiesel purchase was set by the State according to complex formula. ${ }^{14}$ In Europe, biodiesel consumption was subject to similar if not more complex rules. For example, in addition to the requirement that biodiesel comprise a minimum share (7\%) of consumer diesel, some Member States of the EU had additional incentives in place to use biodiesel

\footnotetext{
13 See Crowley and Palmeter (2009) for a discussion of the difficulty of proving "directs and entrusts" claims in the Korean DRAMs case.

14 Commission Regulation (EU) No 490/2013 of 27 May 2013, Section 1.1, paragraph (44).
} 
manufactured from recycled vegetable oils or animal fats. ${ }^{15}$ Moreover, "In some Member States, quota systems are in place that give a particular production quota to companies in that Member State or in other Member States across the Union." 16 In sum, it is difficult to present a baseline "market" price for biodiesel anywhere in the world. While the EU threw out the regulated, government-set Argentine price as not suitable for Normal Value, prices in Europe were also driven by government regulations and interventions. ${ }^{17}$ This implies that it would be sensible to assess dumping using cost data, rather than by comparing output prices across markets subject to different distortions.

\section{The market for soybeans and biodiesel inputs}

Raw soybeans are a commodity whose price is determined by the forces of global supply and global demand. Argentina is a major world producer of soybeans; in 2001, Argentina's share of the world market for soybeans and soybean meal was $24 \%$ (See Schnepf, Dohlman, and Bolling; 2001, p. 2). According to the USDA, over 2002-2015, Argentina's differential export tax system provided stronger incentives for Argentine farmers to produce soybeans over wheat or corn. This led to increased acreage for soybeans and made Argentina a dominant player in the global soybean market. (See Lee, Tran, Jansen and Ash; 2016). Together, these facts suggest that Argentina, as a major supplier, was able to exert some market power over international prices through its export tax policy.

To understand the full impact of the Argentine export tax on soybeans, we need to know the world export supply elasticity. Broda, Limao and Weinstein (2008) present the export supply elasticity for soybeans facing five countries - China, the Czech Republic, Oman, the Russian Federation and Saudi Arabia - at the HS04 level (1201). The average elasticity over these countries is 140, but the range is enormous, from a high of 446 (the Russian Federation) to a low of 0.4 (Saudi Arabia). Soderberry (2015) shows that the use of different methodologies yields extremely different estimates of the export supply elasticity facing the US; the traditional Feenstra/Broda and Weinstein methodology yields an estimate consistent with a perfectly elastic export supply curve while Limited Information Maximum Likelihood finds that the US faces a highly inelastic (0.08) export supply. This wide range of estimates highlights how difficult it is to gage the conditions of market competition with standard econometric methodologies. The Argentine position was essentially that Argentina faced a somewhat inelastic world supply curve while the Europeans assumed a perfectly elastic world supply curve. The evidence presented above tends to support the Argentine position, but is far from conclusive.

A perfectly elastic world supply curve for soybeans would imply full pass through of any Argentine export tax to the domestic price. A 10\% export tax would induce a 10\% decline in the domestic price in Argentina and no change in the price of soybeans in Europe. In contrast, a relatively inelastic export supply curve combined with a relatively inelastic import demand curve for soybeans in foreign markets would imply that the burden of any Argentine export tax would be split between Argentine soybean producers and consumers of soybeans in foreign markets. That is, as a large supplier of soybeans, Argentina likely had market power that not only reduced the domestic price of soybeans for Argentine biodiesel producers, but also drove up the world market price of soybeans for European biodiesel producers.

We can thus conclude that the Argentine export tax led to a large input price decline which represented a beneficial cost shock for biodiesel producers. The questions this raises, from the perspective of economics, are, firstly, was this beneficial cost shock passed through to the price of

15 See Commission Regulation (EU) No 490/2013 of 27 May 2013, Section 3.7, paragraphs (143)-(145).

16 Commission Regulation (EU) No 490/2013 of 27 May 2013, Section 3.8, paragraphs (150).

17 The US market is also heavily influenced by government regulation: "According to the U.S. Department of Energy, there are reportedly more than 300 state laws, regulations and "funding opportunities" related to biodiesel production and use." USITC, "Biodiesel from Argentina and Indonesia: Investigation Nos. 701-TA-571-572 and 731-TA-1347-1348," p. I-19, May 2017. 
exported biodiesel, secondly, if so, by how much, and thirdly, does this amount to unfair government subsidization of biodiesel producers? A related question is: did the export tax drive up the cost of soybeans and soybean oil in Europe, placing European biodiesel producers at a disadvantage relative to their Argentine competitors?

We would expect that the Argentine pricing strategy in response to an input cost shock would depend on the elasticity of demand in the output market. ${ }^{18}$ If demand were highly elastic, we would expect the firm to pass through low input prices to a low output price and increase its market share. This type of behavior would appear consistent with the Article 2.2 definition of dumping. However, if demand were relatively inelastic, we would expect the firm to keep its output price high in order to extract larger profits. Interestingly, over the investigation period of 2009-2012, the price of Argentina's exported biodiesel rose 54\%. At the same time, its market share increased modestly from $7.6 \%$ to $10.8 \%$. These facts suggest that the Argentine firms were likely absorbing the cost advantage conferred by the Argentine export tax into a larger profit margin. That is, Argentine biodiesel producers would have been able to undercut their European competitors substantially, yet they appear to have exploited their market power to capture high profit margins. From an economics perspective, the pricing strategy seems to be at odds with traditional definitions of dumping. Rather, the export tax on soybeans conferred a financial benefit on biodiesel producers that was similar to a production subsidy but had the added benefit of placing European competitors at a cost disadvantage by raising the price of soybeans on world markets. ${ }^{19}$

\section{Conclusion}

The true problem with the export tax on soybeans is that the policy falls into an ambiguous area of legal interpretation in which firms' pricing strategies don't look like dumping and the government intervention doesn't quite fit the SCM's definition of a subsidy. However, the policy clearly had a harmful effect on import-competing biodiesel producers in Europe. In addition to providing a cost advantage to Argentine producers, it seems probable that the export tax directly drove up the costs of European producers, placing them at a competitive disadvantage.

The ultimate question for international economic relations is thus if firms in an importing economy are suffering a competitive disadvantage because of a foreign government policy, how should this be dealt with at the WTO? Are the WTO's unfair trade rules capable of neutralizing the distortion on world prices? If the existing rules are inadequate for this type of problem - a distortion in a vertically integrated industry that benefits an exporter - then what new rules would it be appropriate for the WTO to adopt?

The AB's decision - that the EU regulation violated the WTO rules because a private firm cannot be found to have dumped when its only crime was to purchase inputs at the prevailing (but distorted) prices in its domestic market - has some merit in following the letter of the law. However, the finding

18 Broda, Greenfield and Weinstein (2006) provide estimates of import demand elasticities for biodiesel in a number of European countries. They place the estimate for HS 151 in Germany at 1.75, in the UK at 2.31 and in France at 7.66. For HS 271, their estimates are 5.00, 1.96, and 33, for Germany, the UK and France, respectively.

19 To be precise, biodiesel production in Europe uses rapeseed rather than soybeans as its primary feedstock. However, soybeans and rapeseed are closely substitutable commodities. This implies that an increase in the price of soybeans on world markets places upward pressure on the price of rapeseed, placing EU biodiesel producers at a cost disadvantage. According to the USDA: "World oilseed trade consists of many closely substitutable commodities, such as soybeans, rapeseed, sunflowerseed, and cottonseed. ... The volume and source of foreign imports depends on seasonal availability and relative prices, credit and delivery terms, local preferences, and quality." (https://www.ers.usda.gov/topics/crops/soybeans-oil-crops/trade/) Similarly, a 2008 report from the European Commission highlights the substitutability of rapeseed with imported oilseeds noting that because of increased biodiesel production, "EU rapeseed is being diverted from the food market, to be replaced by imported oilseeds and oils." (De Santi, et. al., 2008). 
also greatly curtails the future discretion of importing countries in trying to develop trade policies to address market distortions that are not transparently subsidies or do not confer a direct benefit on the domestic producers of the product subject to an investigation. The case points to a short-coming of the WTO that will likely become more important over time as trade between Western-style capitalist economies and economies with other forms of resource allocation increases. 


\section{TABLE I: Synopsis of Claims and Findings}

\begin{tabular}{|c|c|c|c|c|}
\hline Claim & Argentina & EU & Panel & $A B$ \\
\hline ADA 2.2.1.1 & $\begin{array}{l}\text { EU failed to calculate } \\
\text { costs on basis of records } \\
\text { kept by producers; EU is } \\
\text { required to use actual } \\
\text { costs incurred in } \\
\text { Argentina by Argentine } \\
\text { producers }\end{array}$ & $\begin{array}{l}\text { Costs in records kept by } \\
\text { producers were distorted } \\
\text { by export tax system and } \\
\text { did not "reasonably reflect } \\
\text { the costs associated with } \\
\text { the product... " The EU } \\
\text { looked to Argentine } \\
\text { reference price } \\
\text { (international price) } \\
\text { instead. }\end{array}$ & $\begin{array}{l}\text { Violation by failing to } \\
\text { calculate cost of } \\
\text { production on basis of } \\
\text { records kept by producers } \\
\text { and on basis of actual } \\
\text { costs to the producers }\end{array}$ & $\begin{array}{l}\text { Violation = EU determination } \\
\text { that domestic prices lower than } \\
\text { international prices due to } \\
\text { export tax was not, in itself, a } \\
\text { sufficient basis for concluding } \\
\text { that producers' records do not } \\
\text { reasonably reflect costs or for } \\
\text { rejecting producers' books and } \\
\text { records }\end{array}$ \\
\hline ADA 2.2 & $\begin{array}{l}\text { Failure to construct NV } \\
\text { on basis of actual costs } \\
\text { in Argentina; EU cannot } \\
\text { use outside prices to } \\
\text { determine costs in } \\
\text { Argentina }\end{array}$ & $\begin{array}{l}\text { Not required to use actual } \\
\text { costs when costs do not } \\
\text { reflect reality; requirement } \\
\text { would break general } \\
\text { standard of reasonableness; } \\
\text { EU used prices Argentine } \\
\text { producers would have paid } \\
\text { absent distortions }\end{array}$ & $\begin{array}{l}\text { Violation by using "costs" } \\
\text { for inputs that was not } \\
\text { cost prevailing in } \\
\text { Argentina }\end{array}$ & $\begin{array}{l}\text { Violation = can use outside } \\
\text { information but must ensure it } \\
\text { "arrives at" or "yields" the COP } \\
\text { in the country of origin; } \\
\text { surrogate used by EU did not } \\
\text { represent actual cost of } \\
\text { soybeans paid by Argentine } \\
\text { biodiesel producers }\end{array}$ \\
\hline ADA 2.4 & $\begin{array}{l}\text { Failure to make due } \\
\text { allowance for } \\
\text { differences affecting } \\
\text { price comparability }\end{array}$ & $\begin{array}{l}\text { Panel correctly found that } \\
\text { EU made permitted } \\
\text { allowances for differences } \\
\text { affecting price } \\
\text { comparability }\end{array}$ & No violation & $\begin{array}{l}\text { Unnecessary to rule, although } \\
\text { disagreed with Panel's finding of } \\
\text { a general proposition in EC- } \\
\text { Fasteners (China 21.5) that } \\
\text { differences arising from } \\
\text { methodology for NV cannot be } \\
\text { challenged under ADA 2.4. }\end{array}$ \\
\hline ADA 9.3 & $\begin{array}{l}\text { Imposing AD duties in } \\
\text { excess of margins of } \\
\text { dumping }\end{array}$ & $\begin{array}{l}\text { Margin of dumping was } \\
\text { properly calculated using } \\
\text { the reference price for } \\
\text { soybean costs }\end{array}$ & $\begin{array}{l}\text { Violation } b / c \text { AD margins } \\
\text { in excess of what should } \\
\text { have been if had used } \\
\text { actual costs }\end{array}$ & $\begin{array}{l}\text { Violation = duties imposed were } \\
\text { in excess of margin of dumping }\end{array}$ \\
\hline $\begin{array}{l}\text { ADA } 3.1 \text { and } \\
3.5\end{array}$ & $\begin{array}{l}\text { EU's own overcapacity } \\
\text { to produce biodiesel } \\
\text { caused the injury, not } \\
\text { Argentine imports and } \\
\text { EU improperly adjusted } \\
\text { its capacity data }\end{array}$ & $\begin{array}{l}\text { EU's non-attribution } \\
\text { analysis was not based on } \\
\text { or affected by revised } \\
\text { capacity utilization data. }\end{array}$ & No violation & $\begin{array}{l}\text { No violation = EU calculations } \\
\text { not tainted by revised data; EU } \\
\text { conclusion on role of } \\
\text { overcapacity was proper. }\end{array}$ \\
\hline $\begin{array}{l}\text { As such 2(5) } \\
\text { EU Basic } \\
\text { Regulation/ } \\
2.2 .1 .1\end{array}$ & $\begin{array}{l}\text { Provision that } \\
\text { authorities shall reject } \\
\text { or adjust costs when } \\
\text { costs reflect prices that } \\
\text { are "abnormally or } \\
\text { artificially low" }\end{array}$ & $\begin{array}{l}2(5) \text { not inconsistent; } \\
\text { replicates } 2.2 .1 .1+ \\
\text { procedures when records to } \\
\text { not reflect costs }\end{array}$ & No violation & $\begin{array}{l}\text { No violation/no panel error b/c } \\
\text { EU law does not require use of } \\
\text { information from other markets } \\
\text { that does not reflect cost in } \\
\text { producer market }\end{array}$ \\
\hline $\begin{array}{l}\text { As such 2(5) } \\
\text { EU Basic } \\
\text { Regulation/ } \\
2.2\end{array}$ & $\begin{array}{l}\text { Provision permitting } \\
\text { adjustment "on any } \\
\text { other reasonable basis, } \\
\text { including information } \\
\text { from representative } \\
\text { markets." }\end{array}$ & $\begin{array}{l}\text { Provision permits but does } \\
\text { not require EU to use costs } \\
\text { from outside country of } \\
\text { origin; only applies after } \\
\text { determination that records } \\
\text { do not reflect costs }\end{array}$ & No violation & $\begin{array}{l}\text { No violation b/c EU can use } \\
\text { other information to construct } \\
\text { costs in manner consistent with } \\
\text { ADA }\end{array}$ \\
\hline $\begin{array}{l}\text { As such 2(5) } \\
\text { EU Basic } \\
\text { Regulation } \\
\text { /Art XVI:4 }\end{array}$ & $\begin{array}{l}\text { Provision permitting } \\
\text { adjustments on any } \\
\text { other reasonable basis }\end{array}$ & $\begin{array}{l}\text { Argentina did not meet its } \\
\text { burden just by showing } \\
\text { provision could be applied } \\
\text { in WTO inconsistent way }\end{array}$ & No violation & No violation \\
\hline
\end{tabular}




\section{References}

Bown, Chad P. and Alan O. Sykes. 2008. "The Zeroing Issue: A critical analysis of Softwood V," World Trade Review 7(1), 121-142.

Broda, Christian, Nuno Limao, and David E. Weinstein. 2008. "Optimal Tariffs and Market Power: The Evidence." American Economic Review, 98(5): 2032-65. DOI: 10.1257/aer.98.5.2032

Crowley, Meredith A. and Howse, Robert. "US-Stainless Steel (Mexico)," World Trade Review (2010), 9: 1, $117-150$.

Crowley, Meredith A. and Palmeter, David, "Japan - Countervailing Duties on Dynamic Random Access Memories from Korea (DS 336 and Corr.1, adopted 17 December 2007)," World Trade Review (2009), 8: 1, 259-272.

De Santi, Giovanni; Edwards, Robert; Szekeres, Szabolcs; Neuwahl, Frederik; Mahieu, and Mahieu, Vincent. "Biofuels in the European Context: Facts and Uncertainties." European Commission, Joint Research Centre. 2008.

Horn, H. and Mavroidis, P. "European Community - Antidumping Duties on Malleable Cast Iron Tube or Pipe Fittings from Brazil," World Trade Review (2006), 5(S1), 87-129.

Lee, Tani; Tran, Anh; Hansen, James, and Ash, Mark. "Major Factors Affecting Global Soybean and Products Trade Projections," Amber Waves, US Department of Agriculture, Economic Research Service, 2 May 2016. (https://www.ers.usda.gov/amber-waves/2016/may/major-factors-affecting-globalsoybean-and-products-trade-projections/)

Prusa, Thomas J. and Vermulst, Edwin. "A One-Two Punch on Zeroing: US-Zeroing (EC) and USZeroing (Japan),” World Trade Review (2009) 8:187-241.

Schnepf, Randall D.; Dohlman, Erik, and Bolling, Christine. "Agriculture in Brazil and Argentina: Developments and Prospects for Major Field Crops," Market and Trade Economics Division, Economic Research Service, US Department of Agriculture, Agriculture and Trade Report. WRS01-3. November 2001.

Soderbery, Anson. "Estimating Import Supply and Demand Elasticities: Analysis and Implications." Journal of International Economics, 96(1), May 2015: pp 1-17. 


\section{Author contacts:}

\section{Meredith A. Crowley}

Faculty of Economics

University of Cambridge

Austin Robinson Building

Sidgwick Avenue

Cambridge, CB3 9DD, UK

Email: meredith.crowley@econ.cam.ac.uk

\section{Jennifer A. Hillman}

Georgetown University Law Center

600 New Jersey Avenue NW

Washington, DC 20001

USA

Email: jah95@law.georgetown.edu 